\title{
Psychology of ustoychivost': numerical scale for assessing human's ustoychivost' according to the golden ratio rule
}

\author{
Vyacheslav Kazankov ${ }^{1, *}$, Vladimir Gubin ${ }^{2}$ \\ ${ }^{1}$ St. Petersburg University of the State Fire Service EMERCOM of Russia, St. Petersburg, Russia \\ ${ }^{2}$ Leningrad State University named after A.S.Pushkin, St. Petersburg, Russia
}

\begin{abstract}
Exploring man, the modern psychology of Europe and America began to actively apply the concepts stability and/or resistance that, in Russia psychology, are combined into one concept - ustoychivost'. In modern psychology, there is no methodology for numerically assessing human ustoychivost'. The article presents the author's scale of numerical evaluation of ustoychivost 'person and outlines an approach to the formation of its road map. Human ustoychivost 'refers to his ability to maintain health at the psychophysiological, psychological and psychosocial levels of life, forming the unity of the individual, personality and the subject of work in a person. Three hypotheses are put forward. Hypothesis 1: it is possible to numerically establish human ustoychivost ' if you create a scale for assessing it by applying the golden ratio rule - the stability scale for the golden ratio (SUGP). Hypothesis 2: if a person subjectively evaluates his ustoychivost 'in the range from 0.382 to 0.618 , then objectively he is stability; if a person subjectively evaluates his ustoychivost 'in the intervals from 0.382 to 0 or from 0.618 to 1 , then objectively he is resistance. To test the hypotheses put forward, an experiment on a sample of firefighters is presented, which confirms their fidelity, and also indicates the appropriateness of using SUGP in extreme psychology, labor psychology.
\end{abstract}

\section{Introduction}

Exploring man, the modern psychology of Europe and America began to actively apply the concepts stability and/or resistance that, in Russia psychology, are combined into one concept - ustoychivost' Kazankov V.V. \& Gumenyuk O.V. [1]. That is, stability + resistance = ustoychivost', which is more informative from the point of view of modern psychology. R. Bellman noted the great overload of the word "stability" and it's not settled definition, and R.Ashby pointed out that the nomenclature of the concept "stability" is unsatisfactory and confusing Kazankov V.V. [2)], but it more likely refers to the concept "ustoychivost' ". A review of the literature on psychological resistance and ustoychivost 'reveals interest in this area Kazankov V.V. \& Gumenyuk O.V. [1], Fletcher D. \& Sarkar M. [3] and Joyce1 S. \& Shand F. [4], reinforcing the importance of psychological health and ustoychivost' personality, which is a condition for the full functioning and development of a

\footnotetext{
* Corresponding author: kazankov-74@mail.ru
} 
person throughout his life Sekach M.F., Perelygina E.B., Zotova O.Y. [5]. In her work Bonanno G.A. [6], is true that most of the published works on resistance focus on linking each new concept to preexisting ones, but this is done in an isolated way. And while psychologists are looking for causal relationships of the concept of "resistance", it's semantic field is constantly evolving and expanding the conceptualization of the definition Fletcher D. \& Sarkar M. [3], and language can become an obstacle to the correct interpretation of the conceptual apparatus and a common-sense snare for science, which leads to the problem of the reliability of the psychological language for scientific psychology Bonnano, G. A., \& Mancini, A. D. [7]. This situation leads to the problem of numerical assessment of human ustoychivost'.

The purpose of the current study is to present for discussion a scale of numerical evaluation of person ustoychivost' and an approach to the formation of her road map. Hypothesis 1: numerically establish ustoychivost 'of a person is possible if you create a scale for its assessment, applying the golden ratio rule — the golden ratio stability scale (SUGP). Ustoychivost 'of a person is his ability to maintain health at the psychophysiological, psychological and psychosocial levels of life, forming in man a unity of the individual, personality and subject of labor Kazankov V.V., YuliLi \& HuayuBai [8, 9] in biotechnosociety - the world of nature, technology, society.

Psychophysiological, psychological and psychosocial levels form a road map for human ustoychivost' markers. Psychophysiological level is the nervous system in determining the individual's mental activity. Psychological level is emotions that form the mental state of the individual. Psychosocial level is volitional manifestation of the orientation of the labor subject.

Psychophysiological level $(\varphi)$ is the registration of the physiological reactions of an individual when ustoychivost' of a person is established by markers: cardiovascular system (blood pressure relative to normal); eye reactions and facial expressions; skin reactions (sweating), etc. Through the nervous system through feedback lines, physiological markers are interpreted by psychic markers: attention, expressed as a perception of information; thinking reflected in logic, decision-making, etc.

Psychological level $(\psi)$ is the registration of emotions and mental states of a person, when a human ustoychivost' is established by markers: valency (tone) of emotions, their intensity (strength), activity and content, which forms emotional, activation, tonic and tensile mental states with their characteristic markers. Psychosocial level $(\kappa)$ is registration of the volitional manifestation of the orientation of the labor subject, when human ustoychivost' is registered with markers: the ability to consciously choose the actual demand, motive, with the subsequent delivery of the goal; the ability to own and control your own behavior; the presence of a worldview and beliefs, united by the concepts of "life" and "activity".

Not all markers are presented above due to their diversity. The psychologist is able to independently create an individual road map, depending on the goals of the ustoychivost' assessment of a person.

\section{Materials and Methods}

Of the source Wang L. \& Shi Z. [10] and works Windle G, Bennett KM, Noyes J. [11], L.Campbell-Sills \& M.B. Stein [12] lay the idea of the possibility of numerical interpretation of markers of each level on SUGP. Important in the construction of SUGP is the totality of all aspects of the personality, its internal unity in the ratio of three parts of one whole according to the golden ratio rule: the whole (psychophysiological level $(\varphi=1)$ ) relates to the greater part (psychological level $(\psi=0.618)$ ), how the greater part refers to the smaller part of the whole (psychosocial level $(\kappa=0.382)$ ) (Fig. 1), which is verified by the golden ratio rule according to formula (1): 


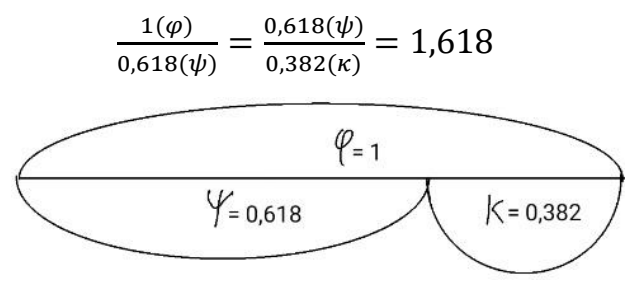

Fig. 1. A figurative interpretation of the correlation of psychophysiological $(\varphi=1)$, psychological $(\psi=0.618)$ and psychosocial $(\kappa=0.382)$ levels in a person.

Presented in fig. 1 dividing the whole into parts not only indicates the hierarchy of levels according to their importance for human ustoychivost', but also the ability to quantify ustoychivost' if you set the figurative segment from 0 to 1 and divide it in the extreme and middle ratio (in the golden ratio). That is, in the interval from 0 to 1 , it is necessary to postpone the conditional current equal to 0.618 (Fig. 2 (A)). Subtracting the point 0.618 (point 1) from the whole, we get the second point 0.382 (Fig. 2 (B)). By superimposing the drawings on each other, we get a stability interval of 0.382 to 0.618 - a human comfort and health interval, stability zone (Fig. 2 (C) with the sign (+)). In the intervals from 0,382 to 0 or from 0.618 to 1 is the instability of a person - the interval of stress and risk, discomfort and vulnerability of a person, resistance zone (Fig. 2 (C) with a sign (-)). Figure 0.5 is the point of balance and harmony of a person, the acme zone (Fig. 2 (C)).

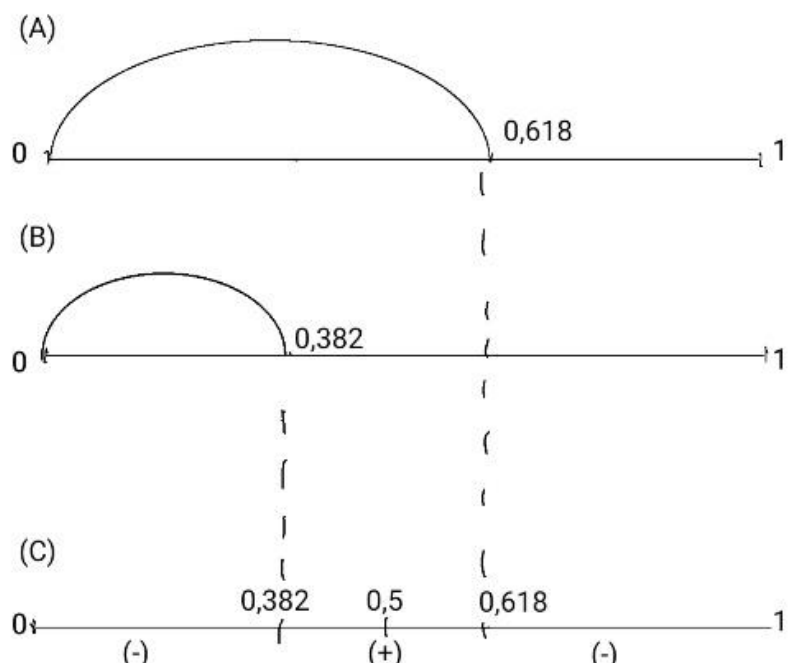

Fig. 2. Visual interpretation of SUGP.

On fig. 2 digits 0 and 1 represent ustoychivost "dead points" beyond which irreversible (irrevocable) processes of human decomposition and degradation begin. Therefore, SUGP is represented by a temporary segment of ustoychivost 'of a person in a biotechnosociety space with two zones: from 0.382 to 0.618 (stability zone); from 0,382 to 0 or 0.618 to 1 (resistance zone). SUGP is applicable for determining ustoychivost 'on $\varphi, \psi$ and $\kappa$ according to the hologram principle from position Khan Adil \& Mavers Scott [13] and Ahmad S. A. \& Abdullahi, I. M [14] that is, $\varphi=(0-1), \psi=(0-1), \kappa=(0-1)$ in a single figurative interpretation (Fig. 1). 
Hypothesis 2: if a person subjectively evaluates his ustoychivost 'in the range from 0.382 to 0.618 , then objectively he is stability; if a person subjectively evaluates his ustoychivost 'in the intervals from 0.382 to 0 or from 0.618 to 1 , then objectively he is resistance.

The total ustoychivost 'of a person is measured in relative units (r.u.) and is determined by the formula (2):

$$
\Omega=\frac{\Omega \varphi+\Omega \psi+\Omega \kappa}{n}(r . u .)
$$

Where,

$\Omega$ is total ustoychivost 'of a person (r.u.);

$\mathrm{n}$ is the number of ustoychivost 'levels, usually 3;

$\Omega \varphi$ is ustoychivost 'at the psychophysiological level (r.u.);

$\Omega \psi$ is ustoychivost 'at the psychological level (r.u.);

$\Omega \kappa$ is ustoychivost 'at the psychosocial level (r.u.);

$\Omega \varphi, \Omega \psi$, and $\Omega \kappa$ are calculated using the same formula (3):

$$
\Omega \varphi, \Omega \psi, \Omega \kappa=\frac{\sum m}{n}(r . u .)
$$

Where,

$\mathrm{m}$ - is numerical values, equivalent markers for evaluating $\varphi, \psi, \kappa$ (each marker is evaluated from 0 to 1 in (r.u.)).

$\mathrm{n}-$ is the number of measured markers.

It follows from formula (3) that the more markers of each level are registered on SUGP, the more objectively and informatively the numerical value of the total ustoychivost 'of a person is calculated. Hypothesis 3: according to SUGP it is possible not only to separately assess the ustoychivost 'of a person at each level $(\varphi, \psi, \kappa)$, but also to instantly evaluate his overall ustoychivost'.

The upcoming $(\tau 1)$ characterizes the person's $\Omega$ before entering the situation;

The present $(\tau 2)$ characterizes the person's $\Omega$ directly in the situation;

The passed ( $\tau 3$ ) characterizes the person's $\Omega$ after leaving the situation.

Testing hypotheses $1,2,3$ were carried out experimentally not in laboratory conditions using the following algorithm.

Respondents were asked to evaluate ustoychivost' three times at three levels $(\varphi, \psi, \kappa)$ by SUGP: before receiving the task $(\tau 1)$; during task execution $(\tau 2)$; after completing the task $(\tau 3)$. The significance level of the task for respondents is above average, is of an examination nature. The results obtained were recorded in three identical tables (Table 1) with an indication of the time interval. That is, three tables in the form (Table 1) were collected from one respondent.

Table 1. Ustoychivost' assessment ( $\tau_{1}$ or $\tau_{2}$ or $\left.\tau_{3}\right)$.

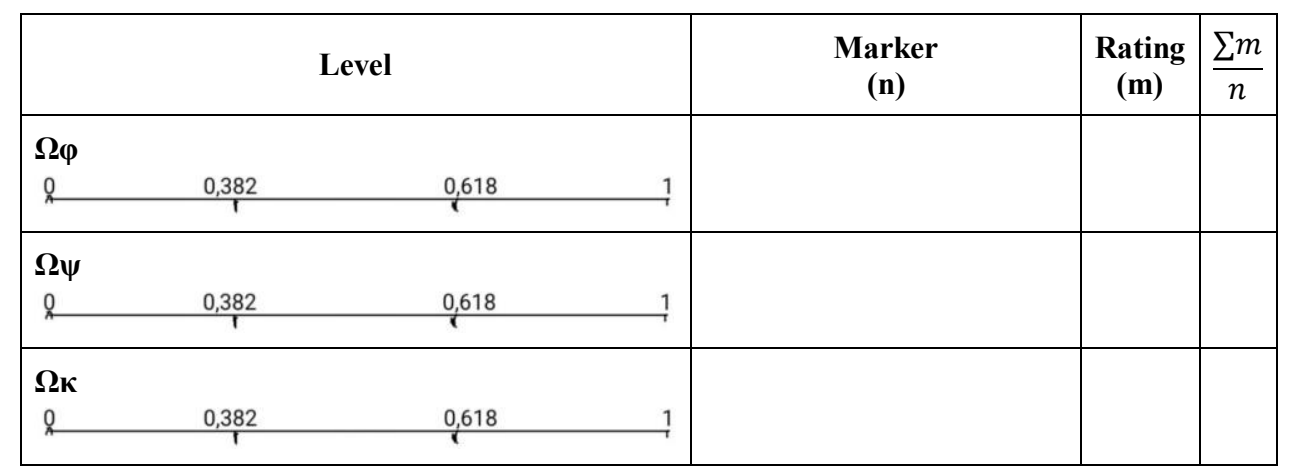




$$
\Omega=\frac{\Omega \varphi+\Omega \psi+\Omega \kappa}{n}(r . u .)
$$

During ustoychivost' registration of SUGP at each time interval, respondents also tested stress resistance questionnaires to verify the results of questionnaires with SUGP results.

When a person is in a limited time interval (stressful (operational) situation), then he has no time to use all subjective markers of ustoychivost' assessment and register their points on SUGP. In such cases, it was proposed to determine $\Omega$ in the interval from 0 to 1 by the method of instant self-assessment, answering one question: "Where is my ustoychivost' point?" ». The result was evaluated on SUGP (Fig. 3).

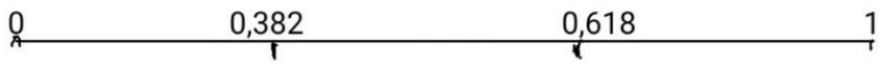

Fig. 3. SUGP assessment of total ustoychivost' $(\Omega)$.

The validity of SUGP was studied over 10 years by comparing the results of respondents in a total sample of 1200 people, where 600 people used SUGP (experimental sample (ES)), another 600 people did not use it (control sample (CS)). Each sample consisted of such categories of respondents as graduate students - 150 people, 75 people in each sample; firefighters - 700 people, 350 in each sample; rescuers - 200 people, 100 in each sample; police officers - 150 people, 75 in each sample.

This article presents the results of testing SUGP for a sample of respondents - firefighters (700 people, 350 respondents in ES and CS). There is an Act for the implementation of scientific results, including SUGP, in the Main Directorate of the Ministry of Emergencies of Russia for the Leningrad Region of December 6, 2010. The experiment consisted of four stages.

Stage 1. At this stage, ES and CS were tested using the Kettell 16-factor personality questionnaire: scale A, scale C, scale O, scale Q3, scale F1, scales O-Q4, scales G-Q3 Ralph L [15] and Sixbey M.T. [16].

Stage 2. Six months after testing, an introductory briefing was given with ES firefighters on how to use SUGP when evaluating the overall ustoychivost' $(\Omega)$ following Fig. 3 . Then they evaluated $\Omega$ before leaving for the fire when they got into the fire engine $(\tau 1)$; at the entrance to the fire situation, before leaving the fire truck $(\tau 2)$; when following to the fire department after a fire, in a fire truck ( $\tau 3)$.

CS firefighters, according to the presented algorithm, had to intuitively evaluate their ustoychivost ' $\Omega$ without knowledge of SUGP.

Stage 3. Six months after the second stage, an introductory briefing was given with ES firefighters on how to use SUGP to evaluate ustoychivost ' $\Omega \varphi, \Omega \psi, \Omega \kappa$. Then they evaluated $\Omega \varphi, \Omega \psi, \Omega \kappa$ by SUGP in accordance with Table. 1 before leaving for a fire, when they got into a fire engine $(\tau 1)$; at the entrance to the fire place, before leaving the fire truck $(\tau 2)$; when following to the fire department after a fire, in a fire truck $(\tau 3)$.

CS firefighters had to intuitively evaluate ustoychivost ' $\Omega \varphi, \Omega \psi, \Omega \kappa$, according to the algorithm presented above, in accordance with Table 1.

Stage 4. Six months after the third stage, firefighters ES and CS were retested as in the first stage.

\section{Results}

The results of stage 1 are presented when considering stage 4 .

The results of stage 2 (Table 2 ). 
Table 2. General data on the assessment of its total ustoychivost' $(\Omega)$.

\begin{tabular}{|c|c|c|c|}
\hline & \multirow{2}{*}{$\begin{array}{l}\text { Number of } \\
\text { respondents }\end{array}$} & \multirow{2}{*}{$\frac{\text { Rate (could / could not) }}{\Omega}$} & \multirow{2}{*}{$\frac{\text { Ratio in\% }}{\Omega}$} \\
\hline & & & \\
\hline \multicolumn{4}{|c|}{$\tau_{1}$} \\
\hline ES by SUGP & 350 & 350/0 & $100 / 0$ \\
\hline CS without SUGP* & 350 & $\mathbf{5 8} / 292$ & $16,5 / 83,5$ \\
\hline \multicolumn{4}{|c|}{$\tau_{2}$} \\
\hline ES by SUGP & 350 & $350 / 0$ & $100 / 0$ \\
\hline CS without SUGP* & 350 & $8 / 342$ & 2/98 \\
\hline \multicolumn{4}{|c|}{$\tau_{3}$} \\
\hline ES by SUGP & 350 & 350/0 & $100 / 0$ \\
\hline CS without SUGP* & 350 & $123 / 227$ & $35 / 65$ \\
\hline
\end{tabular}

* Note. CS respondents began to evaluate $\Omega$ by their personal understanding of the word in the interpretation of "Yes, ustoychivost", "No, not ustoychivost ". The answers "I don't know how to answer" or "I can't evaluate" were equated to the answer category "No". Respondents could not explain what exactly is under the verbal interpretation, however, they were able to describe on what basis they draw relevant conclusions regarding ustoychivost'.

Table 3. Interpretation of $\Omega$ at intervals in ES estimates.

\begin{tabular}{|c|c|c|c|c|}
\hline \multirow{2}{*}{$\begin{array}{c}\text { Level: } \\
\text { interval }\end{array}$} & \multirow{2}{*}{$\begin{array}{c}\text { Number of } \\
\text { respondents }\end{array}$} & \multicolumn{3}{|c|}{$\boldsymbol{\Omega}$} \\
\cline { 3 - 5 } & $\mathbf{3 5 0}$ & 341 & 8 & 1 \\
\hline $\boldsymbol{\tau}_{\mathbf{1}} \mathbf{E S}$ & $\mathbf{3 5 8 2 - 0 , 6 1 8}$ & $\mathbf{0 , 3 8 2 - 0}$ & $\mathbf{0 , 6 1 8 - 1}$ \\
\hline $\boldsymbol{\tau}_{\mathbf{2}} \mathbf{E S}$ & $\mathbf{3 5 0}$ & 296 & 54 & 0 \\
\hline $\boldsymbol{\tau}_{\mathbf{3}} \mathbf{E S}$ & $\mathbf{3 5 0}$ & 350 & 0 & 0 \\
\hline
\end{tabular}

The results of stage 3

Table 4. General data on the assessment of its ustoychivost'.

\begin{tabular}{|c|c|c|c|c|c|c|c|}
\hline & \multirow{2}{*}{$\begin{array}{l}\text { Number of } \\
\text { respondents }\end{array}$} & \multicolumn{3}{|c|}{ Rate (could / could not) } & \multicolumn{3}{|c|}{ Ratio in \% } \\
\hline & & $\mathbf{\Omega} \varphi$ & $\mathbf{\Omega \psi}$ & $\mathbf{\Omega \kappa}$ & $\mathbf{\Omega \varphi}$ & $\mathbf{\Omega} \psi$ & $\mathbf{\Omega \kappa}$ \\
\hline \multicolumn{8}{|l|}{$\tau_{1}$} \\
\hline ES by SUGP & 350 & 311/39 & $295 / 55$ & 246/104 & 89/11 & $84 / 16$ & $70 / 30$ \\
\hline CS without SUGP* & 350 & $\mathbf{4 5} / 305$ & $\mathbf{3 8} / 312$ & $\mathbf{0} / 350$ & $13 / 87$ & $11 / 89$ & $\mathbf{0} / 100$ \\
\hline \multicolumn{8}{|l|}{$\tau_{2}$} \\
\hline ES by SUGP & 350 & 333/17 & $315 / 35$ & $346 / 4$ & $95 / 5$ & 90/10 & 99/1 \\
\hline
\end{tabular}




\begin{tabular}{|l|l|l|l|l|l|l|l|}
\hline CS without SUGP & 350 & $\mathbf{3 5} / 314$ & $\mathbf{8} / 342$ & $\mathbf{0} / 350$ & $\mathbf{1 0} / 90$ & $\mathbf{3} / 97$ & $\mathbf{0} / 100$ \\
\hline \multicolumn{1}{|l}{$\boldsymbol{\tau}_{\mathbf{3}}$} & 350 \\
\hline ES by SUGP & 350 & $\mathbf{3 5 0} / 0$ & $\mathbf{3 5 0} / 0$ & $\mathbf{3 5 0} / 0$ & $\mathbf{1 0 0} / 0$ & $\mathbf{1 0 0} / 0$ & $\mathbf{1 0 0} / 0$ \\
\hline CS without SUGP & 350 & $\mathbf{2 1 5} / 135$ & $\mathbf{1 1 3} / 237$ & $\mathbf{0} / 350$ & $\mathbf{6 1} / 39$ & $\mathbf{3 2} / 68$ & $\mathbf{0} / 100$ \\
\hline
\end{tabular}

Table 5. Decryption of ustoychivost' score from table 4.

\begin{tabular}{|c|c|c|c|c|c|c|c|c|}
\hline $\begin{array}{l}\text { Level: } \\
\text { interval }\end{array}$ & \multicolumn{3}{|c|}{ ES } & \multicolumn{3}{|c|}{ CS } & ES & CS \\
\hline \multicolumn{9}{|l|}{$\tau_{1}$} \\
\hline & 311 & 295 & 246 & 45 & 38 & 0 & $\%$ & $\%$ \\
\hline $\begin{array}{l}\Omega \varphi: \\
0.382- \\
0.618 \\
0.382-0 \\
0.618-1\end{array}$ & $\begin{array}{l}254 \\
51 \\
6\end{array}$ & & & $\begin{array}{l}24 \\
17 \\
4\end{array}$ & & & $\begin{array}{l}81.6 \\
16.4 \\
2\end{array}$ & $\begin{array}{l}53.3 \\
37.7 \\
9\end{array}$ \\
\hline $\begin{array}{l}\Omega \psi: \\
0.382- \\
0.618 \\
0.382-0 \\
0.618-1\end{array}$ & & $\begin{array}{l}215 \\
65 \\
15\end{array}$ & & & $\begin{array}{l}31 \\
6 \\
1\end{array}$ & & $\begin{array}{l}73 \\
22 \\
5\end{array}$ & $\begin{array}{l}81.6 \\
15.8 \\
2.6\end{array}$ \\
\hline $\begin{array}{l}\boldsymbol{\Omega}: \\
0.382- \\
0.618 \\
0.382-0 \\
0.618-1\end{array}$ & & & $\begin{array}{l}211 \\
31 \\
4\end{array}$ & & & 0 & $\begin{array}{l}85.8 \\
12.6 \\
1.6\end{array}$ & 0 \\
\hline \multicolumn{9}{|l|}{$\tau_{2}$} \\
\hline & 333 & 315 & 346 & 35 & 8 & 0 & $\%$ & $\%$ \\
\hline $\begin{array}{l}\Omega \varphi: \\
0.382- \\
0.618 \\
0.382-0 \\
0.618-1\end{array}$ & $\begin{array}{l}324 \\
0 \\
9\end{array}$ & & & $\begin{array}{l}35 \\
0 \\
0\end{array}$ & & & $\begin{array}{l}97 \\
0 \\
3\end{array}$ & $\begin{array}{l}100 \\
0 \\
0\end{array}$ \\
\hline $\begin{array}{l}\Omega \psi: \\
0.382- \\
0.618 \\
0.382-0 \\
0.618-1\end{array}$ & & $\begin{array}{l}305 \\
0 \\
10\end{array}$ & & & $\begin{array}{l}8 \\
0 \\
0\end{array}$ & & $\begin{array}{l}97 \\
0 \\
3\end{array}$ & $\begin{array}{l}100 \\
0 \\
0\end{array}$ \\
\hline 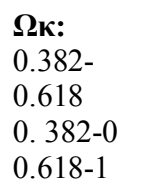 & & & $\begin{array}{l}298 \\
9 \\
39\end{array}$ & & & 0 & $\begin{array}{l}86 \\
3 \\
11\end{array}$ & 0 \\
\hline
\end{tabular}




\begin{tabular}{|l|l|l|l|l|l|l|l|l|}
\hline & $\mathbf{3 5 0}$ & $\mathbf{3 5 0}$ & $\mathbf{3 5 0}$ & $\mathbf{2 1 5}$ & $\mathbf{1 1 3}$ & $\mathbf{0}$ & $\mathbf{\%}$ & $\mathbf{\%}$ \\
\hline $\mathbf{\Omega} \boldsymbol{}:$ & & & & & & & & \\
$0.382-$ & 319 & & & 198 & & & 91 & 92 \\
0.618 & 6 & & & 17 & & & 2 & 8 \\
$0.382-0$ & 25 & & & 0 & & & 7 & 0 \\
$0.618-1$ & & & & & & & \\
\hline
\end{tabular}

The results of stage 1 and 4 .

Table 6. Comparison of average values of results for 16 PF Kettella in stage 1 and in step 4.

\begin{tabular}{|c|c|c|c|c|}
\hline \multirow{2}{*}{ Scale 16 PF } & \multicolumn{2}{|c|}{ ES } & \multicolumn{2}{c|}{ CS } \\
\cline { 2 - 5 } & stage 1 & stage 4 & stage 1 & stage 4 \\
\hline A & 5.6 & 8.6 & 5.5 & 6.7 \\
\hline C & 4.3 & 6.3 & 5 & 5.6 \\
\hline O & 7.8 & 2.8 & 8 & 5 \\
\hline $\mathrm{Q}_{3}$ & 5.9 & 7.9 & 6 & 6.7 \\
\hline $\mathrm{F}_{1}$ & 5.6 & 4.6 & 6.3 & 5.1 \\
\hline $\mathrm{G}_{-} \mathrm{Q}_{3}$ & 4.6 & 6.6 & 4.1 & 4.9 \\
\hline $\mathrm{O}_{-} \mathrm{Q}_{4}$ & 7.9 & 3.9 & 7.4 & 5.4 \\
\hline
\end{tabular}

\section{Discussion}

The results of the study (Table 2) show that the majority of CS respondents were not able to evaluate their ustoychivost 'because they are not familiar with this concept. However, intuitively, they evaluate ustoychivost 'on the principle of "Yes, stable" and "No, unstable". Herewith it is observed that when returning to the fire department, $35 \%$ of firefighters were able to identify ustoychivost', which indicates the resolution processes at the psychophysiological, psychological and psychosocial levels and the state of satisfaction from completing the task. Markers of ustoychivost' assessment were the psychophysiological perceptions of one's body through the cardiovascular system (a clear feeling of a heartbeat and an increase in heart rate); skin reaction (the appearance of sweating of the palms and armpits); motor markers (the presence of tremor of the hands). Similar markers were identified in ES, which indicates their priority and comprehensibility without special knowledge in this area and the possibility of a numerical interpretation in the form of an assessment on SUGP for the subjective perception of the sensations of your body. From tables 2 and 3 it follows that all ES respondents were able to evaluate their ustoychivost', which indicates the simplicity and comprehensibility of SUGP (Fig. 3). At the same time, most firefighters indicated the stability zone (from 0.382 to 0.618 ) before leaving for the fire $(\tau 1)$, at the entrance to the fire site $(\tau 2)$ and when returning to the fire department after the fire $(\tau 3)$, which is a good indicator for the profession "fireman".

The data in the table. 4 indicate that when CS respondents were told about the presence of $\Omega \varphi, \Omega \psi, \Omega \kappa$, they could not understand the psychosocial ustoychivost' $(\Omega \kappa)$ on an intuitive level, but the psychophysiological and psychological ustoychivost 'was especially 
interpreted and evaluated following Table 1, 61\% $(\Omega \varphi)$ and 32\% $(\Omega \psi)$ when moving to the fire department. This fact indicates that if the respondent is in no hurry and is able to carefully look at Fig. 3, then intuitively he is able to evaluate his ustoychivost 'on the psychophysiological and psychological level without specific knowledge about them. At the same time, ES respondents were able to evaluate all levels of ustoychivost' $(\Omega \varphi, \Omega \psi, \Omega \kappa)$ by consciously approaching the assessment intervals. During the conversation it was established: they characterized the interval from 0,382 to 0 by perception with the sign (-), and from 0.618 to 1 with the sign $(+)$, which is true, since this is the resistance zone. The interval from 0.382 to 0.618 by ES respondents was rated as the most reliable, i.e. stability.

From table 5 it follows that at the end of the task in ES and CS there is a maximum percentage of the assessment of their ustoychivost'( $\tau 3)$, which indicates such a functional process as permission to work in the form of a completed task.

Data on testing respondents before entering the experiment and at its exit (Table 6) turned out to be unpredictable. In ES and CS, there is a positive trend in the change of walls on scales characterizing ustoychivost 'of a person. Moreover, in ES they are more pronounced than in CS. This fact indicates a positive therapeutic effect of SUGP, which implies ustoychivost' talk. That is, a staff psychologist, using SUGP, can not only evaluate a person ustoychivost', but also perform a therapeutic effect during a conversation and discussion of SUGP ratings.

The results confirm hypotheses 1, 2, and 3. The experiment showed that SUGP assessment intervals provide an opportunity to quantify the ustoychivost' person. Indeed, a person is subjectively able to evaluate his ustoychivost 'in the range from 0.382 to 0.618 , understanding that objectively he is stable. Also, a person is subjectively able to evaluate his ustoychivost 'in the intervals from 0.382 to 0 or from 0.618 to 1 , realizing that objectively he is resistant This is a conclusion from which it follows that a person is not only theoretically, but also practically able to track periods in his life when he is vulnerable and is at risk under the influence of biotechnosocial stressors. At the same time, he can understand himself in detail, using a three-level assessment of ustoychivost' $(\Omega \varphi, \Omega \psi, \Omega \kappa)$ according to SUGP in the causes of feelings of stress.

The results of the experiment indicate that in its simplicity SUGP can be used every day not only by a psychologist, but also by an ordinary person without any serious time and intellectual costs. The ease of use of SUGP and the reliability of the results allow you to quickly evaluate ustoychivost'.

It should be noted that when a person is in a limited time interval (stressful (operational) situation), he has no time to evaluate ustoychivost 'on the psychophysiological $(\Omega \varphi)$, psychological $(\Omega \psi)$ and psychosocial $(\Omega \kappa)$ levels and register their points on SUGP. In such cases, he can determine the total ustoychivost' $(\Omega)$ in the range from 0 to 1 by instantaneous self-assessment, answering one question: "Where is my ustoychivost 'point?". The resulting answer will subjectively characterize $\Omega$ and, at the same time, indicate the objectivity of $\Omega$ in the case of fixing the first reaction of the answer to the question, which is a relatively accurate reaction of the individual, personality and subject of labor.

During the experiment, numerous and diverse markers of the psychophysiological, psychological and psychosocial levels were obtained for the road map for assessing ustoychivost' person $(\Omega \varphi, \Omega \psi, \Omega \kappa)$, which does not allow us to talk about them in this article, since they are the subject of a separate presentation and evaluation.

The purpose that was set at each stage of the experiment was generally achieved.

\section{Conclusions}

There is no doubt that many may disagree with the presented approach to assessing ustoychivost 'of a person by using the developed SUGP and find it too simple and 
scientifically crude for practical use. However, in psychology there is no alternative solution for a quick assessment of ustoychivost' person, especially in emergency and stressful situations, when it comes to the seconds to make a decision. Moreover, the experiment showed the effectiveness and usefulness of using SUGP, confirmed by the results obtained on samples of other categories of respondents.

At the same time, we must agree that SUGP should be checked for compatibility of the results with the leading world tests, for example, with 16 PF of Kettell. The ustoychivost' roadmap for a person should be subject to close scrutiny.

In conclusion, we note that the efficiency of ustoychivost' assessment by the subject of labor is relevant for specialists in operational and dispatch services. SUGP can serve as an additional tool for a psychologist when working with a patient, and can also be a source of self-control and self-regulation for a person.

\section{References}

1. V.V. Kazankov, O.V. Gumenyuk, Scientific and Technical Journal of St. Petersburg State Polytechnic University. Society. Communication. Education, 130-135 (2010) doi.org/10.24412/Ff8Gw_t4Q7k

2. V.V. Kazankov, Bulletin of the Leningrad State University. A.S. Pushkin, 65-76 (2010) doi.org/10.24412/Ff8E8mTGxIU

3. D. Fletcher, M. Sarkar, European Psychologist 18(1).01, 12-23 (2013) doi.org/10.1027/1016-9040/a000124

4. S. Joyce, F. Shand, J. Tighe, S.J. Laurent, R.A. Bryant, S.B. Harvey, Road to resilience: a systematic review and meta-analysis of resilience training programmes and interventions, http://dx.doi.org/10.1136/bmjopen-2017-017858

5. M.F. Sekach, E.B. Perelygina, O.Y. Zotova, Procedia - Social and Behavioral Sciences 86, 88-92 (2013) https://www.sciencedirect.com/science/article/ pii/S187704281302661X

6. G.A. Bonanno, Am Psychol 59, 20-8 (2004) doi:10.1037/0003-066X.59.1.20

7. G.A. Bonnano, A.D. Mancini, Pediatrics 121, 369-375 (2008) doi: 10.1542/peds.20071648

8. V.V. Kazankov, Scientific and technical statements of St. Petersburg State Polytechnic University. Society. Communication. Education, 127-132 (2010) doi.org/10.24412/Ff8Fj8Jpmc8

9. Yuli Li, Huayu Bai, Fenglan Lou, Fenglin Cao, International Journal of Nursing Sciences 6(4), 406-413 (2019) doi.org/10.1016/j.ijnss.2019.09.002

10. L. Wang, Z. Shi, Y. Zhang, Z. Zhang, Psychiatry Clin Neurosci 64(5), 499-504 (2010) doi.org/10.1111/j.1440-1819.2010.02130.x

11. G. Windle, K.M. Bennett, J. Noyes, Health Qual Life Outcomes 9, 8-18 (2011) doi:10.1186/1477-7525-9-8

12. L. Campbell-Sills, M.B. Stein, J Trauma Stress 20(6), 1019-1028 (2007) doi.org/10.1002/jts.20271

13. A. Khan, S. Mavers, M. Osborne, Conference: Society for Information Technology \& Teacher Education International Conference (2020) https://www.researchgate.net/publication/340819569_Learning_by_Means_of_Hologr ams 
14. S.A. Ahmad, I.M. Abdullahi, M. Usma, IAFOR Journal of Education 3(SE) (2015) https://doi.org/10.22492/ije.3.se.09

15. R.L. Piedmont, Corsini Encyclopedia of Psychology (2010) DOI: 10.1002/9780470479216.corpsy0876

16. M.T. Sixbey, Development of the family resilience assessment scale to identify family resilience constructs (University
http://etd.fcla.edu/UF/UFE0012882/sixbey_m.pdf of Florida, 2005) 